\title{
Development of antioxidant based therapeutics in Unani system of medicine
}

\begin{abstract}
During the last decades several studies have examined the potential role of oxidative stress in the development of various diseases like cancer, Parkinson's disease, Alzheimer's disease, atherosclerosis, myocardial infarction, chronic fatigue syndrome etc. Oxidative stress can cause toxic effects through the production of peroxides and free radicals that damage all components of the cell, including proteins, lipids, and DNA. Unani system of medicine has a wealth of antioxidants that can be incorporated to Unani formulations to prevent and treat diseases arising due to oxidative stress. Drugs like Bandarajoboya (Mellisa officinalis), Aabresham (Bombyxmori), Lehsun (Allium sativum) etc. have already been proven a potent antioxidants. Details can be read in full length paper.
\end{abstract}

Keywords: oxidative stress, antioxidants, reactive oxygen species
Volume II Issue 4 - 2018

\author{
Aliya Parveen,' Mohd Saqlain ${ }^{2}$ \\ Department of Community Medicine, RUMCHRC, India \\ ${ }^{2}$ Department of Kulliyat, RUMCHRC, India
}

Correspondence: Aliya Parveen, Department of Community Medicine, RUMCHRC, India, Email aliyaprvn@gmail.com

Received: June 26, 2018 | Published: August 08, 2018

\section{Introduction}

\section{Oxidative stress}

Oxidative phosphorylation is a normal metabolic pathway in which mitochondria releases energy (ATP-Adenosine triphosphate) by the oxidation of nutrients. As a result of this process ROS (reactive oxygen species) are released from cells which lead to the propagation of free radicals. These ROS (like superoxide, hydrogen peroxides, hydroxyl radical, hydro peroxide, hypochlorous acid, peroxynitrite, alkoxyl etc.) are used by the immune system to attack and kill pathogens. ${ }^{1}$ within the cell they are required to maintain cellular homeostasis. It is estimated that mitochondrial membranes produce approximately $24 \mathrm{nmol} / \mathrm{O}_{2}^{-} /$minutes/ gram of tissue. Majority of which converted to $\mathrm{H}_{2} \mathrm{O}_{2}$ (hydrogen peroxide) by manganese superoxide dismutase (MnSOD). However, when these $\mathrm{O}_{2}^{-}$generating sources remain activated after a physiological stimulus has abated, the continued production of $\mathrm{O}_{2}{ }^{-}$alters cellular redox homeostasis resulting in increased oxidative stress. ${ }^{2}$ The production of ROS damage all components of the cell, including proteins, lipids and Deoxyribonucleic Acid (DNA)leading to various diseases like Cancer, Parkinson's disease, Sickle Cell Disease, lichen planus, vitiligo, Autism, Alzheimer's disease, Atherosclerosis, Myocardial Infarction, Chronic fatigue syndrome etc. ${ }^{3-13}$

\section{Measurement of oxidative stress ${ }^{14}$}

The presence of oxidative stress may be tested in one of three ways:

\section{i. Direct measurement of the ROS}

ii. Measurement of the resulting damage to biomolecules

iii. Detection of antioxidant levels

Directly measuring ROS might seem the preferred method, but many reactive oxygen species are extremely unstable and difficult to measure directly. Because of this, many scientists prefer to measure the damage on proteins, DNA, RNA, lipids, or other biomolecules e.g. Lipid per oxidation by MDA concentration assessment through blood sample. Another approach is to measure the levels of antioxidant enzymes and other redox molecules which serve to counterbalance ROS generated in the cell. Assays are available to measure the activity of specific antioxidant enzymes, such as catalase and superoxide dismutase.

\section{Antioxidants and their mechanism of action}

An antioxidant is a molecule that inhibits the oxidation of other molecules. Oxidation is a chemical reaction that can produce free radicals, leading to chain reactions that may damage cells. Antioxidants such as thiols or ascorbic acid (vitamin C) terminate these chain reactions. The term "antioxidant" is mainly used for two different groups of substances: natural chemicals found in body tissues and outside the body in the form of food, herbs or drugs. To balance the oxidative state, plants and animals maintain complex systems of overlapping antioxidants, such as glutathione and enzymes (e.g., catalase and superoxide dismutase) produced internally or the external source of antioxidants: vitamin A, vitamin C, vitamin E, Flavanoids, $\beta$-Carotene, lycopene and amino acids. ${ }^{15-18}$

\section{Mechanism of action ${ }^{2,19-21}$}

i. Antioxidants work by scavenging ROS

ii. Chelate transition metal ions along with reducing macrophage oxidative stress by inhibition of cellular oxygenases or by activating cellular antioxidants such as glutathione system (an endogenous anti oxidant) that regulates Nitric oxide cycle and reduces ROS. Hence, protects against free radical mediated oxidative damage.

iii. Some of them interacts with superoxide to stabilize it, chelate copper and iron and prevents the production of hydroxyl radicals.

iv. They bind covalently to reactive degradation products of peroxidised lipids, preventing them from reacting with other cellular targets.

v. They also contributes in the production of Nitric oxide (natural vasodilator that helps to maintain normal blood flow in the vessels)

vi. Endogenous antioxidant system work through anti-oxidant enzymes-SOD (Superoxide dismutases), Catalase, Heme 
oxygenase, Glucose-6-phosphate dehydrogenase and glutathione peroxidases.

vii. SOD, dismutate $\mathrm{O}_{2} \bullet-$ to $\mathrm{H}_{2} \mathrm{O}_{2}$ and oxygen.

viii. Catalase, catalyzes the decomposition of $\mathrm{H}_{2} \mathrm{O}_{2}$ to water and oxygen.

ix. Glutathione peroxidases utilize glutathione to reduce $\mathrm{H}_{2} \mathrm{O}_{2}$ and fatty acyl peroxides to water and lipid alcohols respectively.

x. Heme oxygenase catalyzes the oxygen-dependent regiospecific metabolism of heme to $\mathrm{Fe}(\mathrm{II}), \mathrm{CO}$, and biliverdin, which, in turn, is converted to bilirubin via biliverdin reductase

xi. Glucose-6-phosphate dehydrogenase (G6PD) is the first and rate-limiting enzyme in the pentose phosphate pathway and the principal source of intracellular NADPH. NADPH is utilized as a reducing equivalent to maintain thiol redox balance and as a cofactor by other antioxidant enzymes.

\section{Prevention of diseases and Antioxidants ${ }^{22}$}

Antioxidants play a crucial role in human body in the prevention of a number of diseases and maintenance of health-

i. Prevent cardiovascular diseases, cancer and other age related diseases like Parkinson's disease, Alzheimer's disease etc.

ii. Improves vision

iii. Reduce serum total cholesterol levels and prevents oxidation of LDL thus lowers the weight and prevents obesity related diseases like Hypothyroidism, CVDs, Metabolic syndrome, DM etc.

iv. Fight against a number of Skin related problems and keep your skin healthy.

v. Reduce systolic BP

vi. Act as Immunoboosters and improves human's immunity.

vii. Detoxify body thus reduces stress and insomnia.

\section{Unani drugs as Antioxidants ${ }^{23-25}$}

In Unani literature a number of drugs have been mentioned that works as antioxidants Table 1. There is a long list of such type of drugs. And the list goes on. The above mentioned drugs can be used as single or in formulation like syrups, tablets, capsules decoction etc.

Table I Unani drugs as Antioxidants

\begin{tabular}{lll}
\hline S.No & Drugs/Scientific names & $\begin{array}{l}\text { Antioxidant } \\
\text { Content } \\
\text { (mmol/100 g) }\end{array}$ \\
\hline I & Amla(Emblica officinalis) & 301.14 \\
2 & Arjun(Terminalia arjuna) & 146.95 \\
3 & Brahmi Booti(Centella asiatica) & 10.40 \\
4 & Darchini(Cinnamomum zeylanicum) & 139.89 \\
5 & Asl as soos (Glycyrrhiza glabra) & 11.58 \\
6 & Panwaad(Casia tora) & 68.21 \\
7 & Neem(Azadirachta indica) & 89.23 \\
8 & Halela(Terminalia chebula) & 706.25 \\
\hline
\end{tabular}

\begin{tabular}{|c|c|c|}
\hline S.No & Drugs/Scientific names & $\begin{array}{l}\text { Antioxidant } \\
\text { Content } \\
(\mathrm{mmol} / \mathrm{l} 00 \mathrm{~g})\end{array}$ \\
\hline 9 & Rehan(Ocimum sanctum) & 39.67 \\
\hline 10 & Zanjabeel(Zingiber officinale) & 24.37 \\
\hline 11 & Maweez munaqqa(Vitis vinifera) & 108.13 \\
\hline 12 & Ajwa'een(Hyoscyamus niger) & 28.42 \\
\hline 13 & Saadhaj Hindee(Cinnamomum tamala) & 31.29 \\
\hline 14 & Sage(Salvia officinalis) & 102 \\
\hline 15 & Qaranfal(Myrtus caryophyllus) & 465.32 \\
\hline 16 & Zufaa (Hyssopus officinalis) & 38 \\
\hline 17 & Zeera safed(Cuminum cyminum) & 11.88 \\
\hline 18 & Badiyan(Foeniculum vulgare ) & 18.91 \\
\hline 19 & Kabab chini(Pimenta dioica) & 102 \\
\hline 20 & Funduq(Corylus avellana) & 35.51 \\
\hline 21 & Tamar hind(Tamarindus indica) & 12.42 \\
\hline 22 & Badranjboya(Mellisa officinalis) & 125.33 \\
\hline 23 & Pudina (Mentha spicata) & 116.4 \\
\hline 24 & Baboona (Leonurus cardiaca), & 13.19 \\
\hline 25 & Khardal(Brassica juncea) & 10.30 \\
\hline 26 & Bisbasa(Myristica fragrans) & 43.52 \\
\hline 27 & Filfil siyah(Piper nigrum ) & 50.96 \\
\hline 28 & Karanja(Pongamia pinnata) & 21.51 \\
\hline 29 & Gul e surkh(Rosa damascena) & 153.90 \\
\hline 30 & Akleel ul jabal(Rosmarinus officinalis) & 66.92 \\
\hline 31 & Zafraan(Crocus sativus) & 61.72 \\
\hline 32 & Doodhi khurd(Euphorbia hirta) & 61.19 \\
\hline 33 & Zard chob(Curcuma longa) & 15.68 \\
\hline 34 & Nilgiri(Eucalyptus globulus) & 47.30 \\
\hline 35 & Kari patta(Murraya koenigii) & 84.07 \\
\hline 36 & Ood Saleeb(Paeonia officinalis) & 55.13 \\
\hline 37 & Sada bahar(Catharanthus roseus) & 71.4 \\
\hline 38 & Hulba(Trigonella foenum) & 54.79 \\
\hline 39 & Zaitoon(Olea europaea) & 28.6 \\
\hline 40 & Jamalgota(Rhamnus purshiana) & 47.15 \\
\hline 41 & Aabresham(Bombyx mori) & 23.7 \\
\hline 42 & Mastagi(Pistacia lentiscus) & 34.6 \\
\hline 43 & Aas(Myrtus communis) & 27.2 \\
\hline 44 & Lemun(Citrus aurantifolia) & $235.47-888.59$ \\
\hline 45 & Saad koofi(Cyperus rotundus) & 229 \\
\hline 46 & Marzanjosh(Origanum vulgare) & 63.2 \\
\hline 47 & Hasha(Thymus vulgaris & 56.3 \\
\hline 48 & Rumman(Punica granatum & 55.5 \\
\hline 49 & Damm ul akhwain(Dracaena cinnabari) & 2897.11 \\
\hline 50 & Nabar (Ribes nigrum & 97.83 \\
\hline
\end{tabular}




\section{Conclusion}

There is a large body of evidence connecting the effects of oxidative stress on human body resulting in the development of a number of diseases. However, various clinical studies on the role of antioxidants and prevention of numerous health related conditions have been demonstrated. Keeping in mind, the health related benefits of antioxidants, there consumption needs to be heighten. Unani system of medicine has a hoard of such type of drugs possessing antioxidant properties. The need of hour is just to develop antioxidant based therapeutics following clinical trials. Such type of therapeutics can be developed in different formulations according to the need of the patient. If succeeded, we can fight with the epidemic of oxidative stress induced conditions and diseases in time (i.e. Primary prevention).

\section{Acknowledgments}

None.

\section{Conflict of interest}

The author declares that there is no conflict of interest.

\section{References}

1. Singh N, Dhalla AK, Seneviratne C, et al. Oxidative stress and heart failure. Molecular and Cellular Biochemistry. 1995;147(1-2):77-81.

2. Jane A Leopold, Joseph Loscalzo. Oxidative Risk for Atherothrombotic Cardiovascular Disease. Free Radic Biol Med. 2009;12(47):1673-1706.

3. Halliwell Barry. Oxidative stress and cancer: have we moved forward. Biochem J. 2007;401(1):1-11.

4. Valko M, Leibfritz D, Moncol J, et al. Free radicals and antioxidants in normal physiological functions and human disease. International Journal of Biochemistry \& Cell Biology. 2007;39(1):44-84.

5. Singh N, Dhalla AK, Seneviratne C, et al. Oxidative stress and heart failure. Molecular and Cellular Biochemistry. 1995;147(1-2):77-81.

6. Ramond A, Godin-Ribuot D, Ribuot C, et al. Oxidative stress mediates cardiac infarction aggravation induced by intermittent hypoxia. Fundam Clin Pharmacol. 2011; 27(3):252-261

7. Dean OM, Van den Buuse M, Berk M, et al. N-acetyl cysteine restores brain glutathione loss in combined 2-cyclohexene-1-one and D-amphetaminetreated rats: relevance to schizophrenia and bipolar disorder. Neurosci Lett. 2011;499(3):149-153.

8. Diego-Otero Y, Romero-Zerbo Y, el Bekay R, et al. Alpha-tocopherol protects against oxidative stress in the fragile $\mathrm{X}$ knockout mouse: an experimental therapeutic approach for the Fmr1 deficiency. Neuropsychopharmacology. 2009 34(4):1011-1026.
9. Amer J, Ghoti H, Rachmilewitz E, et al. Red blood cells, platelets and polymorphonuclear neutrophils of patients with sickle cell disease exhibit oxidative stress that can be ameliorated by antioxidants. British Journal of Haematology. 2006;132(1):108-113.

10. Aly DG, Shahin RS. Oxidative stress in lichen planus. Acta dermatovenerologica Alpina Panonica et Adriatica. 2010;19(1):3-11.

11. Arican O, Kurutas EB. Oxidative stress in the blood of patients with active localized vitiligo. Acta Dermatovenerol Alp Panonica Adriat. 2008;17(1):12-16.

12. James SJ, Cutler P, Melnyk S, et al. Metabolic biomarkers of increased oxidative stress and impaired methylation capacity in children with autism. Am J Clin Nutr. 2004;80(6):1611-1617.

13. Gwen Kennedy, Vance A Spence, Margaret McLaren, et al. Oxidative stress levels are raised in chronic fatigue syndrome and are associated with clinical symptoms. Free radical biology \& medicine. 2005;39(5):584-589.

14. Anonymous. A review of various oxidative stress testing methods. 2004.

15. Bjelakovic G, Nikolova D, Gluud C. Meta-regression analyses, metaanalyses, and trial sequential analyses of the effects of supplementation with beta-carotene, vitamin $\mathrm{A}$, and vitamin $\mathrm{E}$ singly or in different combinations on all-cause mortality: do we have evidence for lack of harm. PLOS;2013;8(9).

16. Abner EL, Schmitt FA, Mendiondo MS, et al. Vitamin E and all-cause mortality: a meta-analysis. Current Aging Science. 2011;4(2):158-170.

17. Pooja Verma, Sunita Misra. Antioxidants and disease prevention. International Journal of Advanced Scientific and Technical Research. 2014;4(2):903-907.

18. Guiseppe cirillo Fl. Anti oxidant polymer synthesis, properties and application. Wiley. 2012.

19. Mark F Mc Carty, James J, Nicolantonio. $\beta$-Alanine and orotate as supplements for cardiac protection.Open Heart. 2014;1(1):1-9.

20. Ravi Teja Tadimalla. 15 Benefits Of Antioxidants - And How They Keep Us Healthy In A Polluted World. 2018.

21. Aliya Parveen, Zarnigar. Protective Effect of Aabresham (Bombyx Mori) Against Atherosclerosis". International Journal of Ayurvedic and Herbal Medicine. 2008;8(1):3069-3078.

22. Dragland $\mathrm{S}$, Senoo H, Wake K, et al. Several culinary and medicinal herbs are important sources of dietary antioxidants. J Nutr. 2003;133(5):12861290 .

23. Eleanor Healy. The World's Most Antioxidant Rich Foods. 2013.

24. Benzie IFF WG. Herbal Medicine: Biomolecular and clinical aspects. In: B Raton, Eds, UK: Taylor \& Francis; 2011

25. Khare CP. Indian Medicinal Plants. New Delhi: 2007. 